\title{
Feeding Microbe-Fermented Cassava Tuber Wastes Modulates Gut Microbiota and Faecal Characteristics of Growing Pigs
}

\author{
Aro $\mathrm{SO}^{1^{*}}$, Aletor $\mathrm{VA}^{1}$ and Oladunmoye $\mathrm{MK}^{2}$ \\ ${ }^{1}$ Department of Animal Production and Health, Division of Animal Physiology and Reproduction, the Federal University of Technology, Akure, Nigeria \\ ${ }^{2}$ Department of Microbiology, the Federal University of Technology, Akure, Nigeria
}

"Corresponding author: Aro SO, Department of Animal Production and Health, Division of Animal Physiology and Reproduction, the Federal University of Technology, Akure, Nigeria, Tel: +234-706-232-9254; E-mail: soaro@futa.edu.ng

Received date: September 12, 2017; Accepted date: September 21, 2017, Published date: September 28, 2017

Copyright: @ 2017 Aro So, et al. This is an open-access article distributed under the terms of the Creative Commons Attribution License, which permits unrestricted use, distribution, and reproduction in any medium, provided the original author and source are credited.

\begin{abstract}
A four week trial was conducted on 42 weanling pigs to study the effect of feeding differently fermented cassava tuber waste (CTW) diets on faecal parameters and enteric microbial ecology of the experimental animals. Seven different diets were formulated. Three of the diets contained $20 \%$ inclusion of cassava starch residues in the unfermented, naturally fermented and microbially fermented form respectively and were designated unfermented cassava starch residues (UFCSR), naturally fermented cassava starch residues (NFCSR) and microbially fermented cassava starch residues (MFCSR). Three other diets, similarly formulated but with $20 \%$ inclusion of cassava peels were designated as unfermented cassava peels (UFCP), naturally fermented cassava peels (NFCP) and microbially fermented cassava peels (MFCP) respectively. These six CTW diets replaced $30 \%$ of maize in the control diet. The two microbially fermented wastes (MFCSR and MFCP) were processed with a combination of two lactic acid bacteria (Lactobacillus coryneformis and Lactobacillus delbrueckii) and a fungus (Aspergillus fumigatus). The results showed significant differences $(P<0.05)$ in the average faecal output, faecal dry matter, faecal volume, faecal $\mathrm{pH}$ and the total bacterial counts, while the faecal density and the total fungal counts were similar $(P>0.05)$ among the seven dietary treatments. The biochemical characterization of bacterial and fungal isolates from the faecal samples revealed that the highest bacterial biodiversity was recorded in both the NFCSR and MFCP diets while the control group had the least. Of the 17 different fungal species, 6 were isolated from the control group while 2 each were isolated from the two unfermented CTW diets (UFCSR and UFCP). The biochemical characterization of the microbial isolates also showed that the bacteria- Bacillus spp. and Escherichia coli had the highest frequency of occurrence $(100 \%)$ across treatments, while Micrococcus luteus had the least frequency $(28.57 \%)$. The fungusMycotypha microsporium had the highest colonizing ability as it was isolated from the faecal samples of pigs in 4 out of the 7 dietary treatments. Conclusively, feeding the CTW diets to pigs could have a profound influence on growth and faecal parameters and by extension on the digestive physiology of the pigs, also these CTW and their methods of processing could modulate the biodiversity of gut microflora in pigs and possibly in any other livestock species.
\end{abstract}

Keywords: Cassava tuber wastes; Fermentation; Faecal evaluation; Gut microflora

\section{Introduction}

The scarcity of conventional feed resources especially in the developing countries of the world has ever continued to challenge livestock producers to find alternative ways of feeding their livestock if animal production and an uninterrupted supply of animal protein are to be sustained. This challenge has become more imperative now since the developed countries are now diverting their abundant grain reserves hitherto used for feeding livestock and as a famine relief package to some hunger-stricken third world countries to the production of biofuel to propel their huge industrial sector. Chauynarong et al. [1] reported that as a result of the increased use of maize for producing ethanol and biofuel, maize prices in the United States of America rose from $\$ 2.60$ a bushel in 2006 to nearly $\$ 4.00$ a bushel in 2007. The diversion of excess grains for the production of biofuels in this way has put a lot of pressure on the available conventional feed resources especially in the developing countries thereby forcing their prices to a sky-rocketing level often beyond the reach of the average livestock producer.
As a way of confronting this challenge, the use of alternative feed resources has been canvassed [2-4]. The various by-products of cassava tubers like the peels, the sieveates, the fibre etc. have been used variously in many parts of the world for feeding many species of livestock with promising results [3]. The impact of feed on the digestive physiology of farm animals has been well documented $[5,6]$. The type of feed and the form in which it is consumed have been known to have a profound influence on growth performance and general well-being of livestock [7]. Feed has been used as prebiotics to beneficially modify gut microbial population [8] and to improve performance and reduce scouring in piglets [9].

The roles of the gut microbiota often times have been described as a mutually symbiotic relationship [10]. These microorganisms have been known to fulfill a host of useful functions including digestion of unutilized carbohydrates, stimulating cell growth, suppressing/ repressing the growth of harmful microorganisms, training the immune system to respond only to pathogens and defending their host animals against some diseases [10-12]. To our knowledge, these mutually benefiting roles between the type of feed given to livestock and gut microflora have not been investigated in weanling pigs fed microbially fermented cassava tuber waste diets. Therefore, the objective of this study was to investigate the effects of microbially 
fermented CTW diets on growth response, faecal parameters and microbial ecology of weanling pigs.

\section{Materials and Methods}

\section{Sources and preparation of cassava tuber wastes}

The cassava wastes i.e. the cassava peels (CAP) and the cassava starch residues (CSR) were sourced from Matna Foods Limited, Ogbese, Ondo State, Nigeria. These wastes were prepared according to the methods described by Aro et al. [3] and subsequently used in the formulation of the experimental diets designated as follows: Diet I was the control diet with no inclusion of the CTW.

\begin{tabular}{|c|c|c|c|c|c|c|c|}
\hline Ingredients & T1 & T2 & T3 & T4 & T5 & T6 & T7 \\
\hline Maize & 40.00 & 28.00 & 28.00 & 28.00 & 28.00 & 28.00 & 28.00 \\
\hline GNC & 28.43 & 28.43 & 25.82 & 24.66 & 26.95 & 22.16 & 21.32 \\
\hline PKC & 28.57 & 20.57 & 23.18 & 24.34 & 23.05 & 26.84 & 27.68 \\
\hline UFCSR & 0.00 & 20.00 & 0.00 & 0.00 & 0.00 & 0.00 & 0.00 \\
\hline NFCSR & 0.00 & 0.00 & 20.00 & 0.00 & 0.00 & 0.00 & 0.00 \\
\hline MFCSR & 0.00 & 0.00 & 0.00 & 20.00 & 0.00 & 0.00 & 0.00 \\
\hline UNCP & 0.00 & 0.00 & 0.00 & 0.00 & 20.00 & 0.00 & 0.00 \\
\hline NFCP & 0.00 & 0.00 & 0.00 & 0.00 & 0.00 & 20.00 & 0.00 \\
\hline MFCP & 0.00 & 0.00 & 0.00 & 0.00 & 0.00 & 0.00 & 20.00 \\
\hline Bone meal & 1.50 & 1.50 & 1.50 & 1.50 & 1.50 & 1.50 & 1.50 \\
\hline Oyster shell & 0.50 & 0.50 & 0.50 & 0.50 & 0.50 & 0.50 & 0.50 \\
\hline $\begin{array}{l}\text { Vit/min. } \\
\text { premix }\end{array}$ & 0.50 & 0.50 & 0.50 & 0.50 & 0.50 & 0.50 & 0.50 \\
\hline Salt & 0.50 & 0.50 & 0.50 & 0.50 & 0.50 & 0.50 & 0.50 \\
\hline Total & 100.00 & 100.00 & 100.00 & 100.00 & 100.00 & 100.00 & $\begin{array}{l}100.0 \\
0\end{array}$ \\
\hline Crude protein & 20.10 & 20.20 & 20.29 & 20.26 & 20.11 & 20.02 & 20.06 \\
\hline $\begin{array}{l}\text { Energy } \\
\text { (MJ/kg) }\end{array}$ & 12.25 & 11.81 & 11.90 & 11.91 & 12.01 & 11.92 & 11.94 \\
\hline Crude fibre & 6.23 & 7.61 & 7.65 & 7.62 & 6.98 & 7.43 & 6.76 \\
\hline
\end{tabular}

GNC: Groundnut Cake; PKC: Palm Kernel Cake; UFCSR: Unfermented Cassava Starch Residues; NFCSR: Naturally Fermented Cassava Starch Residues; MFCSR: Microbe-Fermented Cassava Starch Residues; UFCP: Unfermented Cassava Peel; NFCP: Naturally Fermented Cassava Peel; MFCP: Microbe-Fermented Cassava Peel.

T1: The control diet; T2: Diet with 20\% UFCSR; T3: Diet with $20 \%$ NFCSR; T4: Diet with 20\% MFCSR; T5: Diet with 20\% UFCP; T6: Diet with 20\% NFCP; T7: Diet with $20 \%$ MFCP.

Table 1: Gross composition (\%) of the experimental diets of the weanling pigs.

Diet II was formulated with $20 \%$ inclusion of unfermented cassava starch residues (20\% UNCSR). Diet III had $20 \%$ inclusion of naturally fermented cassava starch residues (20\% NFCSR). Diet IV had $20 \%$ inclusion of microbe-fermented cassava starch residues (20\% MFCSR). Diets V, VI and VII were formulated with $20 \%$ inclusion of unfermented, naturally fermented and microbe-fermented cassava peels respectively (20\% UNCP, $20 \%$ NFCP and 20\% MFCP). The gross composition of the experimental diets is presented in Table 1.

\section{Experimental animals and their management}

Forty-two cross-bred (Large White $\times$ Duroc Jersey) weanling pigs of about $9.51 \pm 0.32 \mathrm{~kg}$ live weight were purchased from a livestock farm near Akure, Ondo State, Nigeria. The animals were housed in individual pens measuring $2 \mathrm{~m} \times 3 \mathrm{~m}$ and each was equipped with a fixed concrete feeder and drinker. The floor equally was of hard concrete. The roof was even-span and the height of the wall partition was $1.2 \mathrm{~m}$. The height of the roof from the eave to the ground was 3.5 $\mathrm{m}$, a design that ensures straight through ventilation within the pens. The animals were stabilized for two weeks during which they were given shots of Ivermectin to control both internal and external parasites. They were also given Iron dextran and antibiotic (Oxytec L.A.) injections. The animals were fed the experimental diets and water ad libitum during the day throughout the four weeks of the experiment during which records of daily feed intake and weekly weight gain were taken.

\section{Faecal collection}

In the last week of the experiment, the animals were transferred to individual metabolic cages to facilitate easy collection of faecal matter. The total faecal output was collected for seven consecutive days and from this the average faecal output per animal was computed. Also freshly voided faeces from each animal was "captured" within this seven days which were used to determine the faecal volume, faecal $\mathrm{pH}$, faecal moisture, faecal dry matter content, faecal consistency and faecal density.

\section{The faecal volume}

This was determined by measuring the volume of water displaced by a known mass of freshly voided faeces. $50 \mathrm{~g}$ of faecal samples were collected and wrapped in a pre-weighed water proof wrapper (Aluminium foil). This was gently lowered into a graduated measuring cylinder filled with water up to a known volume (initial volume). The rise in volume (final volume) of the water in the cylinder when the faecal sample was gently lowered in was taken as the volume of the faecal sample following the Archimedes principle of floatation. Therefore,

Volume of the faecal sample=Final volume of water in the cylinderThe initial volume.

\section{The faecal density}

The faecal density was determined by dividing the faecal mass by its corresponding volume i.e.:

\section{Faecal density=Faecal mass/Faecal volume $\left(\mathrm{gcm}^{-3}\right)$}

\section{The faecal moisture}

This was computed as the loss in weight as a result of drying a known weight of faecal sample in the oven at a temperature of $105^{\circ} \mathrm{C}$ for $24 \mathrm{~h}$ until a constant weight was achieved. Thus the percentage faecal moisture content i.e.:

$$
\% \text { faecal moisture content }=\frac{W 2-W 3}{W 2-W 1} \times 100
$$


Where W1 is the weight of the Aluminium foil, W2 is the weight of fresh faecal sample+Aluminium foil and W3 is the oven-dried weight of faecal sample+Aluminium foil.

\section{Faecal pH}

This was carried out to ascertain whether there is any effect of dietary treatment on the $\mathrm{pH}$ of the faecal samples. One gram $(1 \mathrm{~g})$ of each fresh faecal sample was weighed and transferred into $20 \mathrm{~mL}$ of distilled water, stirred well to make a solution which was left to settle for about $20 \mathrm{~min}$ during which the $\mathrm{pH}$ electrode was stabilized using $\mathrm{pH} 4$ buffer solution. The electrode was inserted into the test solution and the value read off. The stable values were recorded as the $\mathrm{pH}$ of the test solutions. All the 42 faecal solution were so treated in turn by removing and washing the $\mathrm{pH}$ electrode with distilled water before using it to run the value for a fresh sample.

\begin{tabular}{|l|l|l|l|l|l|l|l|}
\hline \multirow{2}{*}{ Method } & \multicolumn{7}{|c|}{ Observation per isolate } \\
\cline { 2 - 11 } & A & B & C & D & E & F & G \\
\hline Gram's staining & + & + & - & + & + & + & + \\
\hline Shape of cells & S & R & R & R & R & S & S \\
\hline Motility & - & + & + & - & - & - & - \\
\hline Catalase test & - & + & + & - & - & + & + \\
\hline Oxidase test & - & - & - & - & - & - & - \\
\hline Spore formation & - & + & - & - & - & - & - \\
\hline Indole test & - & - & + & - & - & - & - \\
\hline Coagulase test & - & - & - & - & - & + & - \\
\hline Oxidative/fermentation & $-/ F$ & O/F & $-/ F$ & $-/ F$ & $-/ F$ & $-/ F$ & O/F \\
\hline
\end{tabular}

Sugar fermentation:

\begin{tabular}{|l|l|l|l|l|l|l|l|}
\hline Glucose & a & a & ag & a & a & a & a \\
\hline Sucrose & a & a & - & a & a & a & a \\
\hline Mannitol & a & - & a & a & a & a & a \\
\hline Lactose & a & - & a & - & - & a & a \\
\hline Fructose & - & ag & - & a & a & a & a \\
\hline Galactose & a & ag & a & - & a & ag & a \\
\hline
\end{tabular}

Probable organisms: A: Streptococcus faecalis; B: Bacillus spp; C: Escherichia coli; D: Lactobacillus delbrueckii; E: Lactobacillus coryneformis; F: Staphylococcus aureus; G: Micrococcus luteus.

Observations: +: Positive; -: Negative; S: Spherical; R: Rod; O: Oxidation; F: Fermentation; a: Acid forming; g: Gas forming and ag: Acid and Gas forming.

Table 2: Biochemical characterization of bacterial isolates from the faecal samples of weanling pigs fed microbe-fermented CTW diets.

\section{Faecal consistency}

It was carried out to show how well formed or loosely formed the faecal matter was in order to reveal whether the diets provoked a tendency to diarrhoea in the experimental animals. The faecal consistency scoring system of Marquardt et al. [13] which categorized the consistency of faecal matter as normal (0), soft faeces (1), mild diarrhoea (2) and severe diarrhoea (3) was used.

\section{Faecal microbial evaluation}

The microbiota of the faecal samples in terms of the bacterial and fungal populations, were isolated using standard procedures. The bacterial evaluation of the faecal samples was carried out in the Microbiology Department of the Federal University of Technology, Akure, Nigeria where the fresh samples were cultured for bacterial growth. Two hundred and fifty-two (252) McCartney or bijou bottles ( 6 bottles per sample) were used for serial dilution, 42 disposable Petri dishes, nutrient agar, $42(2 \mathrm{ml})$ needles and syringes, masking tape, methylated spirit lamp, spatula, bowl, brush, soap, $90 \%$ alcohol, cotton wool, electronic weighing balance (Precisa 30000DSCS, Precisa Instrument Ltd., Switzerland) and distilled water were also used. Six labelled bijou bottles for each sample were filled with $9 \mathrm{~mL}$ of distilled water, covered and sterilized in an autoclave at $121^{\circ} \mathrm{C}$ for $15 \mathrm{~min}, 14 \mathrm{~g}$ of nutrient agar was weighed, dissolved in $500 \mathrm{~mL}$ of distilled water and autoclaved as well before it was allowed to cool to $50^{\circ} \mathrm{C}$. Approximately $1 \mathrm{~g}$ of each fresh faecal sample was dissolved into the first bottle labelled " $\mathrm{A}$ " for each sample after which $1 \mathrm{~mL}$ of the solution was drawn, transferred and mixed with the sterilized water in bottle "B". This was repeated until the sixth bottle for each sample was so treated. $1 \mathrm{~mL}$ of the content in each of the sixth bottles was then measured into the corresponding labelled Petri dishes and the agar was poured into each carefully and enough to cover the base and then swirled both clockwise and anticlockwise for thorough mixing of the sample solution with the agar. After solidification of the agar, the culture was incubated in inverted position at $37^{\circ} \mathrm{C}$ for $18-24 \mathrm{~h}$. All these inoculation were done inside a previously sterilized laminar flow chamber.

The inverted Petri dishes were observed for bacterial growth after this time interval. Seven different colonies based on their growth pattern and morphology in the agar were observed and were later identified via characterization through gram staining, motility, spore formation, indole, coagulase, oxidase, catalase and sugar fermentation tests. The bacterial population was determined by counting the number of colonies in each plate. The growth and morphological pattern in agar which is a measure of their physical characteristics include shape, size, chromogenesis, opacity, elevation, surface, edge etc.

\section{Characterization tests}

Practical guides as described by Wiley et al. [14] were used in the biochemical characterization of the bacterial isolates.

\section{The Gram stain}

This was used to differentiate the Gram positive i.e. those that retain stain firmly after being treated with basic para-rosalinine dyes like crystal violet, followed by iodine and those that do not.

\section{Catalase test}

This test uses $30 \%$ concentrated $\mathrm{H}_{2} \mathrm{O}_{2}$ on bacterial colony to confirm catalase presence if bubbles were produced and its absence if bubbles were not produced. Catalase is an enzyme that converts $\mathrm{H}_{2} \mathrm{O}_{2}$ to water and oxygen in the following reaction:

$$
2 \mathrm{H}_{2} \mathrm{O}_{2} \stackrel{\text { catalase }}{\longrightarrow} 2 \mathrm{H}_{2} \mathrm{O}+\mathrm{O}_{2}
$$


Page 4 of 9

Catalase test is used to differentiate Streptococcus (negative to catalase test) from Staphylococcus (positive to catalase test) and bacillus (positive) from Clostridium (negative).

\section{Indole production test}

Indole production was confirmed using tryptophan-rich medium to differentiate coliform organisms e.g. Escherichia (indole +) from Enterobacter (indole -).

\section{Sugar fermentation and oxidation tests}

These tests were performed to determine the aerobic (those that utilize sugar in the presence of oxygen) and anaerobic organisms (those that utilize sugar in the absence of oxygen) using glucose, sucrose, mannitol, lactose, fructose and galactose. These sugar fermentation tests are accompanied by acid and gas production with the use of appropriate indicators. Change of the sugar solution from blue to yellow indicate acid production and an inverted Durham tube which shows a space at the bottom of the tube is indicative of gas production.

\section{Coagulase test}

This test uses human plasma and was carried out to differentiate pathogenic from non-pathogenic Staphylococcus through their coagulating ability.

\section{Oxidase test}

This was carried out to differentiate enteric bacteria (all negative) using $1 \%$ aqueous solution of tetramethyl-phenylenediame hydrogen chloride as reagent with which the culture was streaked to observe their oxidative ability. If colonies develop pink colour that successfully turns dark red, purple and black within 10-30 min, then they are oxidase positive. The various biochemical methods used in the characterization of the bacteria isolates are as given in Table 2 .

\section{Evaluation of faecal fungi}

This was carried out in the Diagnostic Unit of the Department of Animal Production and Health Laboratories of the Federal University of Technology, Akure, Nigeria. $4.5 \mathrm{~g}$ of Potato Dextrose Agar (PDA) was diluted in $500 \mathrm{~mL}$ of distilled water and about $0.1 \mathrm{~g}$ chloramphenicol was added to inhibit the growth of other microorganisms in the culture. Following agar sterilization and cooling, the sterile sample solutions ( $9 \mathrm{~mL}$ each) were inoculated with $1 \mathrm{~g}$ of faecal samples from the animals and serially diluted; the sample solution in the sixth bottle was used as in the bacteria culture. The culture was placed in a sterilized inoculating chamber for five days to incubate at room temperature. The population of the fungi was determined by counting the number of visible colonies in each plate as done for bacterial evaluation. Identification of the different species of fungi was done at the Microbiology Department of the Federal University of Technology, Akure, Nigeria.

\section{Results}

\section{Growth response}

Table 3 shows the growth response of the experimental animals to the differently fermented CTW diets. The final weights were similar $(\mathrm{P}>0.05)$ in all the treatments but ranged from $13.66 \mathrm{~kg}$ in pigs fed with the MFCP diet to $14.60 \mathrm{~kg}$ in those fed with the NFCSR diet. The highest $(\mathrm{P}<0.05)$ weight gain was recorded in NFCP diet $(6.28 \mathrm{~kg})$ while the MFCP had the least value $(5.36 \mathrm{~kg})$. The NFCP that had the highest weight gain also had the second highest feed intake $(22.11 \mathrm{~kg})$ while the MFCP with the least weight gain had the least total feed intake $(15.33 \mathrm{~kg})$. The best feed conversion to flesh and the best efficient feed users were the animals on the UFCSR diet.

\begin{tabular}{|c|c|c|c|c|c|c|c|c|}
\hline Parameters & Control & UFCSR & NFCSR & MFCSR & UFCP & NFCP & MFCP & \pm SEM \\
\hline Initial wt(kg) & 8.93 & 8.60 & 8.43 & 8.43 & 8.60 & 8.30 & 8.30 & 0.37 \\
\hline Final wt(kg) & 14.53 & 14.60 & 13.91 & 14.03 & 14.52 & 14.58 & 13.66 & 0.41 \\
\hline Total wt gain(kg) & $5.60^{\mathrm{bc}}$ & $6.00^{\mathrm{ab}}$ & $5.48^{\mathrm{bc}}$ & $5.60^{\mathrm{bc}}$ & $5.92^{\mathrm{b}}$ & $6.28^{\mathrm{a}}$ & $5.36^{c}$ & 0.20 \\
\hline Weekly wt gain(kg) & 1.40 & 1.50 & 1.37 & 1.40 & 1.48 & 1.57 & 1.34 & 0.11 \\
\hline Daily wt gain(g) & 200.00 & 214.29 & 195.71 & 200.00 & 211.43 & 224.29 & 191.43 & 20.00 \\
\hline Total feed intake $(\mathrm{kg})$ & $20.89^{\mathrm{ab}}$ & $15.84^{\mathrm{cd}}$ & $23.73^{\mathrm{a}}$ & $15.79^{\text {cd }}$ & $18.53^{\mathrm{bc}}$ & $22.11^{\mathrm{a}}$ & $15.33^{\mathrm{d}}$ & 0.33 \\
\hline Weekly feed intake $(\mathrm{kg})$ & $5.22^{\mathrm{ab}}$ & $3.96^{\mathrm{cd}}$ & $5.93^{\mathrm{a}}$ & $3.95^{\mathrm{cd}}$ & $4.63^{\mathrm{bc}}$ & $5.53^{\mathrm{a}}$ & $3.83^{\mathrm{d}}$ & 0.13 \\
\hline Daily feed intake $(\mathrm{kg})$ & $0.75^{\mathrm{ab}}$ & $0.57^{\mathrm{cd}}$ & $0.85^{\mathrm{a}}$ & $0.56^{\mathrm{cd}}$ & $0.66^{\mathrm{bc}}$ & $0.78^{\mathrm{a}}$ & $0.55^{\mathrm{d}}$ & 0.02 \\
\hline FCR & 3.73 & 2.64 & 4.33 & 2.82 & 3.13 & 3.52 & 2.86 & 0.36 \\
\hline EFU & 0.23 & 0.38 & 0.23 & 0.35 & 0.32 & 0.28 & 0.35 & 0.04 \\
\hline
\end{tabular}

a,b,c,d: Means in the same row but with different superscripts are statistically $(P<0.05)$ different. UFCSR: Unfermented Cassava Starch Residues; NFCSR: Naturally Fermented Cassava Starch Residues; MFCSR: Microbe-Fermented Cassava Starch Residues; UFCP: Unfermented Cassava Peel; NFCP: Naturally Fermented Cassava Peel; MFCP: Microbe-Fermented Cassava Peel

Table 3: Growth response of weanling pigs fed microbe-fermented CTW diets. 


\begin{tabular}{|c|c|c|c|c|c|c|c|c|}
\hline Faecal parameters & Control & UFCSR & NFCSR & MFCSR & UFCP & NFCP & MFCP & \pm SEM \\
\hline Output (kg/wk) & $2.16^{\mathrm{ab}}$ & $1.47^{\mathrm{d}}$ & $2.17^{\mathrm{ab}}$ & $1.94^{\mathrm{cd}}$ & $1.75^{\mathrm{cd}}$ & $2.46+$ & $1.63^{\mathrm{cd}}$ & 0.11 \\
\hline Dry matter (kg/wk) & $1.00^{\mathrm{a}}$ & $0.58^{\mathrm{c}}$ & $0.87^{a b}$ & $0.69^{b c}$ & $0.69^{b c}$ & $0.96^{\mathrm{a}}$ & $0.96^{\mathrm{a}}$ & 0.06 \\
\hline$\%$ dry matter & $46.48^{a}$ & $39.41^{\mathrm{b}}$ & $39.67^{b}$ & $35.51^{\mathrm{b}}$ & $39.59^{b}$ & $39.07^{b}$ & $34.95^{b}$ & 1.80 \\
\hline$\%$ moisture & $53.52^{\mathrm{b}}$ & $60.59^{a}$ & $60.33^{a}$ & $64.49^{a}$ & $60.41^{a}$ & $60.93^{a}$ & $65.05^{a}$ & 1.80 \\
\hline Volume $\left(\mathrm{cm}^{3}\right)$ & $2.58^{\mathrm{ab}}$ & $1.65^{b}$ & $2.55^{\mathrm{ab}}$ & $3.62^{\mathrm{a}}$ & $1.86^{\mathrm{ab}}$ & $2.80^{\mathrm{ab}}$ & $2.02^{\mathrm{ab}}$ & 0.43 \\
\hline Density $\left(\mathrm{gcm}^{-3}\right)$ & 0.84 & 0.89 & 0.90 & 0.81 & 0.87 & 0.89 & 0.81 & 0.08 \\
\hline $\mathrm{pH}$ & $4.52^{\mathrm{b}}$ & $4.80^{\mathrm{ab}}$ & $4.87^{\mathrm{a}}$ & $4.98^{\mathrm{a}}$ & $4.75^{\mathrm{ab}}$ & $5.02^{\mathrm{a}}$ & $4.87^{a}$ & 0.09 \\
\hline Consistency & 0.50 & 0.83 & 0.83 & 0.83 & 0.83 & 0.83 & 1.00 & 0.21 \\
\hline Bacteria $\left(\times 10^{6}\right)$ & $45.33^{c}$ & $57.33^{\mathrm{bc}}$ & $49.00^{\mathrm{C}}$ & $102.67^{a b}$ & $83.00^{\mathrm{abc}}$ & $150.00^{\mathrm{ab}}$ & $165.00^{\mathrm{a}}$ & 25.57 \\
\hline Fungi $\left(\times 10^{6}\right)$ & $5.00^{c}$ & $2.67^{\mathrm{cd}}$ & $4.00^{c}$ & $11.33^{\mathrm{b}}$ & $4.67^{\circ}$ & $1.00^{d}$ & $14.67^{\mathrm{a}}$ & 3.01 \\
\hline
\end{tabular}

Table 4: Faecal evaluation and microbial population parameters of weanling pigs fed microbe-fermented CTW diets.

\begin{tabular}{|c|c|c|c|c|c|c|c|c|c|}
\hline Isolates & Control & UFCSR & NFCSR & MFCSR & UFCP & NFCP & MFCP & Freq & $\%$ Occ. \\
\hline S. faecalis & + & + & + & + & + & - & + & 6 & 85.71 \\
\hline Bacillus. spp. & + & + & + & + & + & + & + & 7 & 100.00 \\
\hline E. coli & + & + & + & + & + & + & + & 7 & 100.00 \\
\hline S. aureus & - & + & + & - & + & + & + & 5 & 71.43 \\
\hline L. delbrueckii & - & - & + & + & - & - & + & 3 & 42.86 \\
\hline L. coryneformis & - & - & + & + & - & + & + & 4 & 57.14 \\
\hline M. luteus & - & - & - & - & + & + & - & 2 & 28.57 \\
\hline Total isolate/treatment & 3 & 4 & 6 & 5 & 5 & 5 & 6 & & \\
\hline \multicolumn{10}{|c|}{$\begin{array}{l}\text { Freq: Frequency of Occurrence; \% Occ.: Percentage of Occurrence; UFCSR: Unfermented Cassava Starch Residues; NFCSR: Naturally Fermented Cassava Starch } \\
\text { Residues; MFCSR: Microbe-Fermented Cassava Starch Residues; UFCP: Unfermented Cassava Peel; NFCP: Naturally Fermented Cassava Peel; MFCP: Microbe- } \\
\text { Fermented Cassava Peel. }\end{array}$} \\
\hline \multicolumn{10}{|c|}{$\begin{array}{l}\text { Organisms: S. faecalis (Streptococcus faecalis), Bacillus. spp. (Bacillus species), E. coli (Escherichia coli), S.aureus (Staphylococcus aureus), L. delbruecki } \\
\text { (Lactobacillus delbrueckii), L. coryneformis (Lactobacillus coryneformis), M. luteus (Micrococcus luteus). }\end{array}$} \\
\hline
\end{tabular}

Table 5: Bacterial isolates from the faecal samples of weanling pigs fed dietary inclusion of microbe-fermented cassava tuber wastes (CTW).

\section{Faecal evaluation}

Table 4 shows the result of faecal evaluation and microbial population in the faecal samples of pigs on the seven dietary treatments. The largest faecal output per week $(2463.33 \mathrm{~g})$ was observed in pigs fed NFCSR diet while the least faecal output (1468.33 g) was recorded in the UNCSR diet. The largest and least faecal outputs were therefore recorded among the CTW diets while the control diet was intermediate among them. Also faecal output showed statistical significant differences among the treatment means. The dry matter content of the faeces in the control diet had the highest value and was significantly higher $(\mathrm{P}<0.05)$ than the values obtained for the CTW diets except for the NFCP and MFCP diets. The least dry matter content was observed in the UFCP diet. The moisture content was highest in the MFCP diet but had similar $(\mathrm{P}>0.05)$ value with all other CTW diets and was significantly different $(\mathrm{P}<0.05)$ from the control diet which had the least faecal moisture content.

The faecal volume gave values that ranged from $1649.87 \mathrm{~cm}^{3}$ in the UFCSR diet to $3619.97 \mathrm{~cm}^{3}$ in the MFCSR diet. The faecal volumes of these two dietary treatments were statistically different form each other but both were similar to other dietary treatments. The faecal density gave similar $(\mathrm{P}>0.05)$ values across all dietary treatments but the NFCSR had the highest faecal density $\left(0.90 \mathrm{gcm}^{-3}\right)$ while the MFCSR and the MFCP (the two diets whose CTW were fermented with selected microbial inoculums) had the lowest faecal density $(0.81$ $\left.\mathrm{gcm}^{-3}\right)$. The bacterial population was highest $\left(165.00 \times 10^{6} \mathrm{CFU}\right)$ in the MFCP and lowest $\left(45.33 \times 10^{6} \mathrm{CFU}\right)$ in the control diet. The bacterial 
count in the NFCSR gave similar $(\mathrm{P}>0.05)$ values with the control diet while that of MFCSR, though numerically lower, had similar $(\mathrm{P}>0.05)$ value with the NFCP.

\begin{tabular}{|c|c|c|c|c|c|c|c|c|c|c|}
\hline Isolates & Descr. & Ctrl & UFCSR & NFCSR & MFCSR & UNCP & NFCP & MFCP & Freq & $\%$ Occ \\
\hline Mycotypha racemosum & Green & + & - & - & - & - & - & - & 1 & 3.70 \\
\hline Mycotypha microsporum & BG & + & - & + & + & - & - & + & 4 & 14.82 \\
\hline Aspergillus fumigatus & Brown & + & - & - & - & - & - & - & 1 & 3.70 \\
\hline Itersonilia perplexans & WS & + & - & - & - & - & - & - & 1 & 3.70 \\
\hline Streptothrix atra & White & + & - & - & - & - & - & - & 1 & 3.70 \\
\hline $\begin{array}{l}\text { Sporobolomyces } \\
\text { salmomcolor }\end{array}$ & RW & + & - & + & + & - & - & - & 3 & 11.11 \\
\hline Oidiodendron griseum & WC & - & + & - & - & - & - & - & 1 & 3.70 \\
\hline $\begin{array}{l}\text { Trichosporonoides } \\
\text { oedocephalis }\end{array}$ & DG & - & + & - & - & - & + & + & 3 & 11.11 \\
\hline Glicocladium deliquesces & & - & - & + & - & - & - & - & 1 & 3.70 \\
\hline Halosporangium parium & WR & - & - & + & - & - & - & - & 1 & 3.70 \\
\hline Aspergillus spp. & WB & - & - & - & + & - & - & - & 1 & 3.70 \\
\hline Penicillium italicum & DG & - & - & - & + & - & - & - & 1 & 3.70 \\
\hline Articulospora inflata & White & - & - & - & - & + & + & - & 2 & 7.41 \\
\hline $\begin{array}{l}\text { Syncephalastrum } \\
\text { racemosum }\end{array}$ & WEG & - & - & - & - & + & + & - & 2 & 7.41 \\
\hline Geotrichum albidum & White & - & - & - & - & - & + & - & 1 & 3.70 \\
\hline Botryotrichum piluliferum & Grey & - & - & - & - & - & + & + & 2 & 7.41 \\
\hline Penicillium notatum & & - & - & - & - & - & + & - & 1 & 3.70 \\
\hline Total Isolate/sample & & 6 & 2 & 4 & 4 & 2 & 6 & 3 & & \\
\hline
\end{tabular}

Table 6: Fungal species isolated from the faecal samples of the weanling pigs fed microbe-fermented cassava tuber waste (CTW) diets.

The fungal population gave values that were not statistically different $(P>0.05)$, but the highest fungal load was observed in the MFCP and the lowest in NFCP. The two unfermented CTW had the least fungal load. The $\mathrm{pH}$ of all the faecal samples fell within the acidic range. The control diet gave the most acidic faeces ( $\mathrm{pH} 4.52)$ while the NFCP diet had the least acidic faeces ( $\mathrm{pH}$ 5.05).

\section{Bacterial ecology/biodiversity}

The distribution of the bacterial isolates from the faecal samples of the experimental animals is as shown in Table 5. Seven bacteria species were isolated from the pig's faecal samples. The control treatment had the least bacterial biodiversity as only 3 bacteria species were isolated from it while both the NFCSR and MFCP had the highest bacteria biodiversity with 6 of the 7 bacterial species isolated from them. The percentage distribution of all the seven bacterial isolates across all the treatments showed that both Bacillus spp and E. coli were isolated from all the seven dietary treatments (100\% distribution). Streptococcus faecalis was isolated 6 out of the 7 dietary treatments (85.71\% distribution), Staphylococcus aureus from 5 out of the 7 dietary treatments $(71.43 \%$ distribution), Lactobacillus coryneformis from 4 out of 7 treatments (57.14\% distribution), Lactobacillus delbrueckii in 3 out of 7 treatments (42.86\% distribution) while Micrococcus luteus was found in only two of the 7 treatment samples (28.57\% distribution).

\section{Fungal ecology/biodiversity}

The fungal species isolated from the faecal samples of the weanling pigs are as shown in Table 6. Seventeen different fungi were isolated from the faecal samples with the control and NFCP diets having the largest fungal biodiversity (6 of the 17 fungal isolates were characterized from each of these two diets), 2 fungi each from UFCSR and UFCP diets, 4 fungi each from NFCSR and MFCSR diets while 3 
different fungi were isolated from the MFCP diet. The two unfermented CTW diets had the least fungal biodiversity. The fungus with the highest percentage of occurrence (14.82\%) across all the treatments was Mycotypha microsporium which occurred in 4 out of the 7 treatment samples. Sporobolomyces salmomcolor and Trichosporonoides oedocephalis appeared thrice each with $11.11 \%$ of occurrence respectively.

\section{Discussion}

\section{Growth response}

The growth responses of the experimental animals to the differently fermented CTW diets revealed that all but one (NFCSR) of the CTW diets performed numerically better than the control diet as far as the growth response criteria like weight gain, feed conversion ratio and efficiency of feed utilization were concerned. The poor response of pigs fed the control diet to these growth parameters could be as a result of relatively low prevalence and diversity of resident microbiota in their gut as reflected in their faecal matter. In fact, there is accumulated evidence in literature that a decline in microbial diversity in the colon is associated with digestive instability/disturbance $[7,15,16]$. Better growth response in the animals fed microbially fermented CTW diets could have resulted from greater availability of microbe-fermented products like the short chained fatty acids (SCFA) which the animals used as additional sources of energy and nutrients $[10,17,18]$.

Bhandari et al. [7] reported a higher average daily gain of between 236-289 $\mathrm{g}$ and a better gain to feed ratio (efficiency of feed utilization) of between 0.44-0.66 for weanling pigs in their 3 week experiment on raw potato starch. The better growth performance/response in their experiment might not be unconnected with a lower dietary fibre (1.87-2.13) and the more digestible nature of the raw potato starch in their diets. The better feed efficiency in the microbially fermented diets could also have come from enzymes produced by the microflora which improved nutrient uptake, reduced luminal viscosity and increased animals' overall growth performance [19].

\section{Faecal evaluation}

The faecal parameters like faecal output, faecal dry matter, faecal moisture content, faecal $\mathrm{pH}$, faecal volume and faecal bacterial and fungal counts gave statistical significant differences among the treatment means. The faecal $\mathrm{pH}$ for instance was significantly higher in the control diet than in the CTW diets. This could be as a result of the physiological adjustment of the animals' gut function in the alteration of $\mathrm{pH}$ (lowering of intestinal tract acidity) towards the proliferation of micro-organisms in the caecal and colonic section of the gastrointestinal tract because the acidity of the stomach as well as bile secretion in the duodenum and proximal intestine would hinder the proliferation of these gut flora [20]. The highest dry matter content recorded in the control diet could have resulted from a lower rate of fermentation of resistant starch and dietary fibre in the colon of these animals as a result of non-inclusion of microbial inoculums in the ration formulation. The fact that the UFCSR with the best feed efficiency had the lowest faecal dry matter content pointed to the highly fermented nature of the CTWs in the distal gastro-intestinal tract where most of the carbohydrates that escaped enzymatic digestion in the intestine were digested to yield short chain fatty acids (SCFA) which were directly made available to the animals as additional sources of energy and nutrients [11].
Also, the better saccharolytic fermentation of the CTWs in the hind gut might not be unconnected with their different carbohydrate constituents [21] and the varying ability of the colonic microbiota to produce enzymes that could break them down [22]. The two unfermented CTW diets (UFCSR and UFCP) had the lowest faecal volume and these happened to be directly related to their respective faecal output. Since the fermented CTW products had higher faecal volume and output than the unfermented ones, the discrepancy observed could therefore mean that fermentation had effects on the physico-chemical properties like hydration, gelation, water binding and water retaining ability of these CTWs [23-25]. These variations in the physico-chemical properties of the CTWs could also explain differences in the faecal dry matter and moisture content observed among the dietary treatments.

The faecal density gave similar $(\mathrm{P}>0.05)$ values across all the treatments but interestingly, the animals fed with two of the CTWs that were selectively treated with specific microorganisms had the lowest faecal density $\left(0.81 \mathrm{gcm}^{-3}\right)$. The significance of this is that fermentation with lactic acid bacteria like the species used for these two CTWs i.e. Lactobacillus delbrueckii and Lactobacillus coryneformis in consortium with the fungus- Aspergillus fumigatus had the tendency of increasing colonic faecal volume thereby making more surface area of the digesta available for microbial degradation. Buddington and Weiher [26] reported that the addition of fermentable carbohydrates increased dog's intestinal length with more surface area. This increase in the volume of the digesta and by extension in the surface area provides evidence for interaction among the digesta, the resident microbiota and gastro-intestinal characteristics. Since density is one of the environmental factors (gastro-intestinal characteristics) affecting species diversity, these authors opined that identifying the key environmental factors that control the composition of the GIT microbiotic community is one of the several question research needs to answer. Also, in their study with neonatal mice, Hill and Cowley [27] concluded that the change in the density of colonic digesta will enable the GIT bacteria modify their environment i.e. their ecological niche for optimum growth and development.

The faecal bacteria counts were significantly $(\mathrm{P}<0.05)$ higher in the CTW diets than in the control. This could have been as a result of the more fermentable nature of carbohydrates from roots and tubers than those from grains [21]. Zeoula et al. [6] reported that dry matter effective degradability (DMED) of cassava by-products is higher than those of corn, also Dian et al. [28] reported that the dry matter soluble fraction and DMED presented a linear increase when the proportion of cassava by-products replacing corn in the diets increased. The gut microbiotic community thus found the CTW diets a more optimum medium for their proliferation. Their higher population in the prefermented CTW products also supports the view that pre-fermented products present a more conducive environment for intestinal microflora population to flourish because prior fermentation would have released readily utilizable nutrients for the micro-organisms to directly work upon [29]. The statistically different bacterial population in the different diets also revealed the influence of diets at altering or changing the composition and metabolic activities of intestinal microbiota [30].

The fungal population of the faecal matter showed that the highest counts $\left(11.33 \times 10^{6}\right.$ and $\left.14.67 \times 10^{6} \mathrm{CFU}\right)$ were recorded in the two selectively inoculated CTWs i.e. MFCSR and MFCP respectively. Just as it was observed under the faecal bacterial population, the fungal population of the faecal matter of these weanling pigs showed that 
there is dietary effect on fungal population. Fungal growth is most illfavoured in the NFCP and UFCSR diets. The fungal population across treatments was observably low when compared with bacterial population. The plausible explanation is that there could be a form of competitive exclusion against the fungi by the bacteria [31]. Competitive exclusion for substrates, production of anti-microbial metabolites that inhibit pathogens and competition for attachment sites are all factors that could affect microbial population in the gastrointestinal tract (GIT) [32]. Guarner and Malagelada [11] reported on another mechanism for the repression of pathogenic organism called the "barrier effect" by which harmful organisms are prevented from colonizing the gut by the helpful gut flora. These two mechanisms might have prevented the proliferation on fungi in the gut of these weanling pigs.

The faecal consistency scores ranged from 0.50 in the control diet to 1.00 in the MFCP diet. These scores, according to Marquardt et al. [13] range from zero (normal) to 3 (severe diarrhoea). All values fell between 0 (normal) and 1 (soft faeces) indicating either the absence of or mild diarrhoea among the experimental animals which called for a word of caution in the use of the MFCP at least for this category of pigs. This point is also elucidated by the dismal growth response of pigs that fed on this diet. The possible explanation of this observation is the dietary modulation of the gut microbiota towards the proliferation of micro-organisms with diarrheagenic propensities [29].

\section{Bacterial ecology/biodiversity of the pigs' gastro-intestinal tract}

Bhandari et al. [7] in their classification of bacterial isolates from the colon digesta of weanling pigs categorized the bacteria into 6 Phyla made up of 13 Classes, 1 Subclass and 13 Orders using cultureindependent molecular method of terminal restriction fragment length polymerase (T-RFLP) chain reaction of $16 \mathrm{~S}$ rDNA gene. The number of isolates identified by these authors was more than those reported here because this current study used the culture-dependent total plate count. The most diversified organisms are the Bacillus spp. and E. coli having a proportional microbial distribution or percentage occurrence of $100 \%$. They were followed by Streptococcus faecalis (85.71\%) and Staphylococcus aureus (71.43\%) while Micrococcus luteus, found only in the faeces of pigs that fed on UFCP and NFCP diets had the least bio-diversity $(28.57 \%)$. The bacteria that were selectively used to ferment the CTW i.e. L. delbrueckii and L. coryneformis were only found at levels of $42.86 \%$ and $57.14 \%$ in the faecal matter of the pigs respectively.

The higher percentage of occurrence of Bacillus spp., E. coli, $S$. faecalis and $S$. aureus in the faecal samples of the weanling pigs gave credence to the classification of these four micro-organisms under the normal microbiota of the vertebrate GIT [14]. The lactic acid bacteria that were selectively used in the fermentation of CTWs in this study appeared to have a rather very low percentage occurrence despite the fact that they were the candidate organisms used for the fermentation of the sterile substrates (CTWs). The very low occurrence of these lactic acid bacteria could be as result of unfavourable $\mathrm{pH}$ of the colonic digesta to these organisms which are known to proliferate optimally at a $\mathrm{pH}$ of 4.4-4.6 [14]. The very low percentage of occurrence of $M$. luteus was also not unexpected because a higher percentage could have been an aberration judging from the fact that this organism is an obligate aerobe that inhabits soil, water or mammalian skin [14]. Its isolation from the faecal samples in only two of the 7 experimental treatments and from the only unsterilized (NFCP) and unfermented
(UFCP) cassava peel diets gave pointers to its extraneous origin in the faeces and is suggestive of its contamination with the faeces during the act of defaecation.

\section{Fungal ecology/biodiversity}

The dietary treatment with the highest gastro-intestinal fungal biodiversity was the control treatment where 6 different fungi were isolated from the faecal samples of pigs that fed on this diet. The diets with the least fungal isolates were the two unfermented CTW diets (the UFCSR and UFCP diets). Interestingly, the fungal inoculum (Aspergillus fumigatus) that was selectively added to ferment the CTW was only isolated from the faecal samples of pigs fed with the control diet and not in those of pigs fed with the Aspergillus fumigatus inoculated diets. Literature reported that fungi and protozoa also make up part of the gut flora and that the currently known genera of fungi in the gut flora include Candida, Saccharomyces, Aspergillus and Penicillium (Wikipedia). It then means that Aspergillus fumigatus is one of the normal gut micro-organisms, but its absence from the faecal samples of pigs in the two treatments which it was selectively used to inoculate would have been caused by its obliteration from the gut micro-environment through competitive exclusion and "barrier effect" $[11,31]$ earlier on mentioned. The various types of fungi found in the gut of these weanling pigs need further research clarification to ascertain whether they could be included as normal gut flora or whether they are just extraneous contaminants in the faeces.

\section{Conclusion}

This trial lent support to the dietary modulation postulate of the gut micro-environment of vertebrates as observed in the experimental pigs. The variation in types (biodiversity) and population (colony forming units) of micro-organisms in the faecal matter revealed that the different types of feed given to these animals played a major role in dictating the type and number of organisms that were found in the faeces. The faecal parameters investigated also gave significant statistical differences alongside the dietary treatments applied. The possibilities of exerting health benefits, growth promoting effects and treating some gastro-intestinal disturbances by using the diet as a management tool has therefore been highlighted in this trial. Hence, it could be concluded that the digestive physiology and the variants of gut microbiota of pigs and possibly of any mammalian species, is dependent on the type of feed/food consumed and the various processing methods such feed/food had undergone.

\section{References}

1. Chauynarong C, Elangovan AV, Iji PA (2009) The potentials of cassava products in diets for poultry. World's Poultry Sci J 65: 23-35.

2. Aderemi FA (2004) Effect of replacement of wheat bran with cassava root sieviate supplemented or unsupplemented with enzyme on the haematology and serum biochemistry of pullet chicks, Troical. J Animal Sci 7: 147-153.

3. Aro SO, Aletor VA, Tewe OO, Fajemisin AN, Usifo B et al. (2008) Preliminary investigation on the nutrients, anti-nutrients and mineral composition of microbially fermented cassava starch residues. In: Adeyemi OA, Ogungbesan AM, Dada AO, Eniolorunda OO, et al. (Eds.). Proceedings of the 33rd Annual Conference, NSAP, Ayetoro, Ogun State, Nigeria.

4. Sahoo SK, Naskar SK, Panda BK, Mohapatra CM, Padhi MK, et al. (2008) Performance of broilers on replacement of maize with different levels of of whole and peeled cassava tuber meals. Anim Nutr Feed Technol 8: 121-126. 
5. Zeoula LM, Martins AS, Prado IN, Alcade CR, Branco AF, et al. (1999) Ruminal solubility and degradability of starch of different feeds. Revista Brasileira Zootecnia 28: 898-905.

6. Mouro GF, Branco AF, Macedo FAF, Rigolon LP, Mala FJ, et al. (2002) Corn replacement by cassava by-product meal in the lactating goat's diet: Effect on milk production and composition and nutrient digestibility. Revista Brasileira Zootecnia 31: 475-483.

7. Bhandari SK, Nyachoti CM, Krause DO (2009) Raw potato starch in weaned pigs and its influence on post-weaning scours and the molecular microbial ecology of the digestive tract. J Anim Sci 87: 984-993.

8. Englyst HN, Kingman SM, Cummings JH (1992) Classification and measurement of nutritionally important starch fractions. Euro J Clin Nutrition 46: S33-S50.

9. Callensen J, Halasb D, Thorupa F, Bach Knudsen KE, Kimd JC, et al. (2007) The effects of weaning age, diet composition and categorization of creep feed intake by piglets on diarrhoea and performance after weaning. Livestock Sci 108: 120-123.

10. Sears CL (2005) A dynamic partnership: celebrating our gut flora. Anaerobe 11: 247-251.

11. Guarner F, Malagelada JR (2003) Gut flora in health and disease. Lancet 361: 512-519.

12. http://www.eurekalert.org/pub_releases/2004-07/hhmi-gbt072104.php

13. Marquardt RR, Jin LZ, Kim JW, Fang L, Frohlich AA, et al. (1999) Passive protective effect of egg yolk antibodies against enterotoxigenic Escherichia coli $\mathrm{K}^{8} 8^{*}$ infection in neonatal and early-weaned piglets. FEMS Immunol Med Microbiol 23: 283-288.

14. Wiley JM, Sherwood LM, Woolverton CJ (2008) Prescott, Harley and Klein's Microbiology. 7th Edn, The McGraw-hill Companies, New York, USA.

15. Mes TH (2008) Microbial diversity-Insights from population genetics. Environ Microbiol 10: 251-264.

16. Lozupone CA, Knight R (2007) Global patterns in bacterial diversity. Proc Natl Acad Sci U S A 104: 11436-11440.

17. Gibson RG (2004) Fibre and effects on probiotics (the probiotic concept). Clin Nutrition Suppl 1: 25-31.

18. Beaugerie L, Petit JC (2004) Microbial-gut interaction in health and disease. Antibiotic-associated diarrhoea. Best Pract Res Clin Gastroenterol 18: 337-352.

19. Bedford MR (2001) The role of carbohydrases in feedstuff digestion. In: Mcnab J, Boorman KN (Eds.). Poultry feedstuffs: supply, composition and nutritive value. CAB International, Edinburgh, UK.
20. O'Hara AM, Shanahan F (2006) The gut flora as a forgotten organ. EMBO Rep 7: 688-693.

21. Promthong S, Kanto U, Tiwarattanawanich C, Tongyai S, Isariyodom S, et al. (2005) Comparison of nutrient composition and carbohydrate fractions of corn, cassava chip and cassava pellet ingredients: Animals. Proceedings of 43rd Kasetsart University Annual conference, Thailand.

22. Wynne AG, McCartney AL, Brostoff J, Hudspith BN, Glenn GR, et al. (2004) An in vitro assessment of the effects of broad-spectrum antibiotics on the human gut microflora and concomitant isolation of a Lactobacillus plantarum with anti-Candida activities. Anaerobe 10: 165-169.

23. Arragoni E, Caprez A, Amado R, Neukom H (1986) Chemical composition and physical properties of modified dietary fibre sources. Food Hydrocolloids 1: 57-64.

24. Weber JL (1987) The water binding capacity of fruit and vegetable fibres. Ph.D Dissertation, University of Minnesota, MN, USA.

25. Ralet MC, Thibault JF, Della Vale G (1990) Influence of extrusion cooking on the structure and properties of wheat bran. J Cereal Sci 11:249-259.

26. Buddington RK, Weiher E (1999) The application of ecological principles and fermentable fibres to manage gastrointestinal tract ecosystem. J Nutr 129: 1446-1450.

27. Hill RR, Cowley HM (1990) The influence of colonising micro-organisms on development of crypt architecture in the neonate mouse colon. Acta Anat 137: 137-140.

28. Dian PHM, Prado IN, Geron LJV, Lobo AR, Zeoula LM, et al. (2008) Apparent digestibility and in situ degradability of diets with cassava byproducts fed to beef bulls. Archivos de Zootecnia 57: 373-376.

29. Gibson GR, Roberfroid MB (1995) Dietary modulation of the human colonic microbiota: introducing the concept of prebiotics. J Nutr 125: 1401-1412.

30. Netherwood T, Gilbert HJ, Parker DS, O’Donnell AG (1999) Probiotics known to change bacterial community in the avian gastrointestinal tract. Appl Environ Microbiol 65: 5134-5138.

31. Simon O, Jadamus A, Vahjen W (2001) Probiotic feed additiveseffectiveness and expected mode of action. J Animal Feed Sci 10: 51-67.

32. Yang Y, Iji PA, Choct M (2009) Dietary modulation of gut microflora in broiler chickens: a review of role of six kinds of alternatives to in-feed antibiotics. World Poultry Sci J 65: 97-114. 